\title{
BUSINESS BEHAVIOR AND BUSINESS PERFORMANCE OF BATIK ENTREPRENEURS DURING THE COVID PANDEMIC 19
}

\author{
Tona Aurora Lubis ${ }^{1)}$, Firmansyah ${ }^{2)}$ \\ ${ }^{1,2)}$ Faculty of Economic and Business, Jambi, Indonesia \\ Corresponding author: tonalubis@unja.ac.id
}

\begin{abstract}
The emergence of the Covid-19 pandemic has caused huge losses throughout the world. The main victims of this pandemic are micro, small \& medium enterprises (SMEs), including Batik SMEs Industry. During the Covid-19 pandemic, it becomes the basis that there will be fundamental changes in business behavior and performance. In general, the ultimate goal of this research is to model the impact of the Covid 19 Pandemic on business behavior and business performance of Jambi Batik entrepreneurs. This study used qualitative research methods with phenomenological type. This qualitative research analysis will be assisted by using the Nvivo software. Based on research, it can be concluded that the downturn of these business entrepreneurs can be seen from their business behavior and business performance. In terms of business behavior, it can be seen that the batik business in Jambi province is experiencing downturn due to 3 reasons. These are Efficiency, Innovative and Creative, while in business performance, the downturn of batik business entrepreneurs in Jambi Province can be seen from 2 reasons, these are reduced profits and decreased sales turnover.
\end{abstract}

Keywords: Business Behavior, Business Performance, Covid-19, Pandemic

\section{Introduction}

The massive and uncontrolled spread of Covid-19 in various parts of the world has made WHO (World Health Organization) officially announced that Covid-19 has become a world pandemic since March 11, 2020. This pandemic was announced not only as a preparedness for medical needs, but also as a preparedness from various aspects that will be affected, both in the social, cultural and economic fields (Sayuti \& Hidayati, 2021). In response to this preparedness, scientists around the world are racing against time to develop vaccines and find the right cure to treat the debilitating symptoms of this virus as it is considered to continue to wreak havoc on the global economy (Sharma et al., 2020). Several countries issued policies to reduce mobility by imposing lockdowns, large-scale restrictions, travel warnings, locking their borders for incoming and outgoing travel, and limiting mobility in and out of except for essential commodities such as food and medicine (Evans, 2020).

The emergence of the Covid-19 pandemic has caused huge losses throughout the world. Many sectors of the economy are paralyzed. For large companies, the problems faced are related to declining demand, supply chain disruptions, cancellation of export orders, shortages of raw materials, and transportation disruptions(Shafi et al., 2020). However, the main victims of this pandemic are micro, small \& medium enterprises (SMEs). It happened becausecompared to large companies, SMEs do not have sufficient resources, especially in terms of financial and managerial capabilities (Bartik et al., 2020). In fact, the SMEs sector is one of the biggest contributors to a country's economic growth (Kumar et al., 2020).

Several previous studies has already discussed about the impact of the Covid-19 pandemic on SMEs. Among them, research (Sayuti \& Hidayati, 2021) which highlights that in general most SMEs are affected by this pandemic. The impact is in the form of reduced income, reduction of employees, as well as changes in quantity and production systems. Research (Zainuddin, 2020) also adds that several important fentrepreneurs such as access to financing, supply chains, and social networks have a significant effect on SMES business performance in Malaysia during the pandemic. (Ameji et al., 2020) in his research on Nigerian SMEs also explained that the supply of labor as a factor of human production experienced a significant reduction. This is because workers seem to be experiencing difficulties due to movement restrictions as a result of policies during the pandemic.

Meanwhile, research of (Sunarjo et al., 2021) explains that the impact received by SMEs is due to the many systems that force cashless sales and electronic payments as a form of Covid-19 prevention. This is not well received by some SMES entrepreneurs who still carry out conventional transactions. Supporting this research, (Syaifullah et al., 2021) added that the use of electronic payments mediated by social media resulted in a positive effect on SMEs during the pandemic.

On the other hand, (Gerald et al., 2020) who researched SMEs in Anambra, Nigeria stated that the Covid19 pandemic would not have that big impact on SMEs if SMEs had the foresight to observe what was happening in other countries and were quick to respond in making policies and changes to their operations. In line with that, SME players continue to implement business strategies so that income remains stable. SMEs are expected to be able to make rational, strategic, vigilant and innovative data-based business decisions in 
managing operations during a pandemic (Christa \& Kristinae, 2021; Damilola et al., 2020; Fabeil et al., 2020).

One type of SMEs that is quite important in Indonesia is Batik craft. The Ministry of Industry (Kemenperin) noted that the national export value of batik handicrafts throughout the first semester of 2019 reached USD 17.99 million or equivalent to Rp. 253.897 billion. The main destinations of Indonesian batik exports are to Japan, the United States, and Europe. Meanwhile, according to the Jambi City Industry and Trade Office, the largest Jambi batik cluster is located in the Seberang area of Jambi City and there are more than 31 Jambi batik motifs that can still be found. Among them are Muaro Jambi temple motifs, Angso duo and so on. The impact of the COVID-19 pandemic on SMEs is explained in research (Prabowo et al., 2020) which states that during the Covid-19 pandemic, it becomes the basis that there will be fundamental changes in people's behavior. This change in behavior can be seen from the reduced public perception of the need for batik both in terms of quantity and frequency of purchase.

Based on the literature that has been described previously, it can be concluded that there are changes in business performance and behavior that have emerged in the business sector, especially SMEs during the pandemic. Therefore, this research is an interesting and important study to examine the Business Behavior and Business Performance of Jambi Batik Businesses during the Covid 19 Pandemic.

\section{Research Method}

The object of this research is Jambi batik businessmen in Jambi city. This research is a qualitative research with phenomenological type. This research was analyzed qualitatively using Nvivo

\section{Result and Discussions}

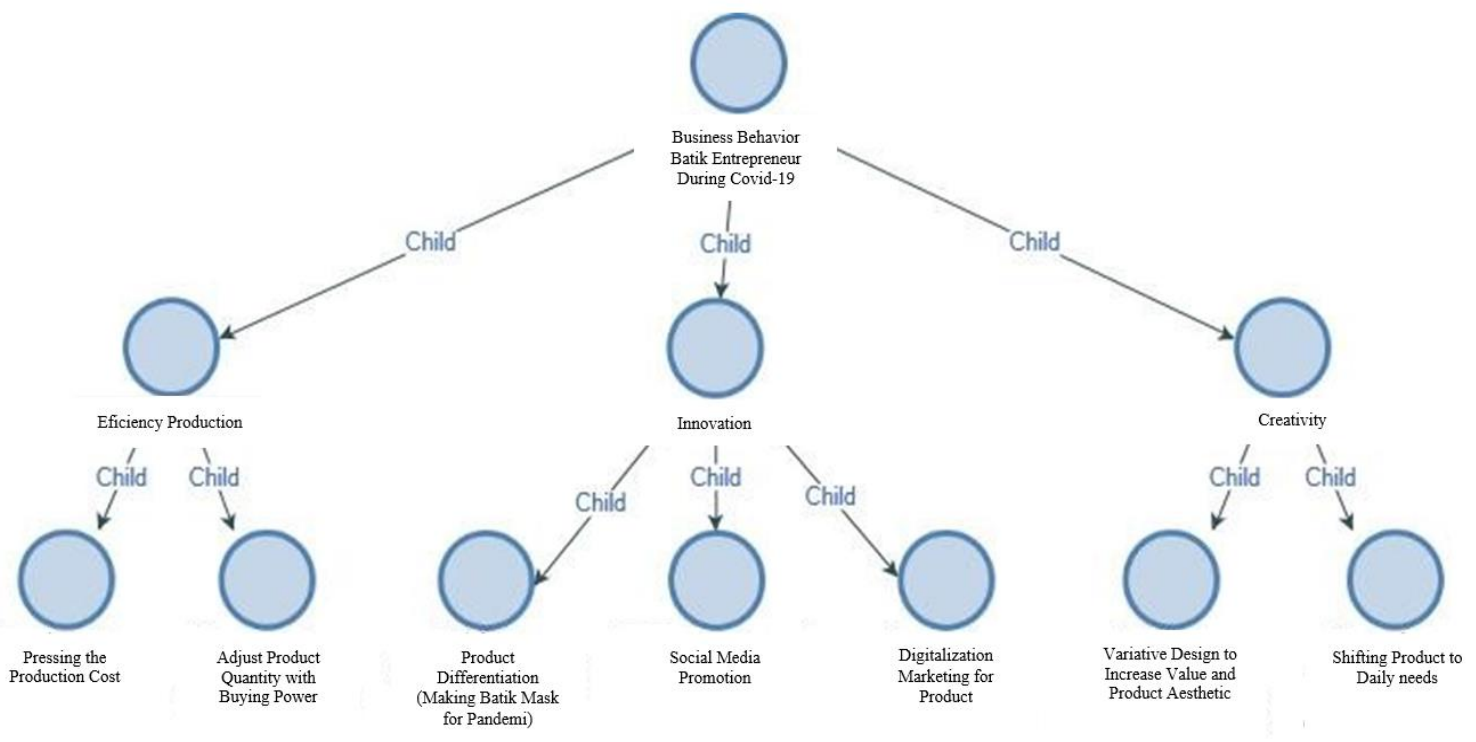

Figure 1. Project Map of Batik Business Conduct during Covid-19

Figure 1 is an output result calculated by NVIVO software. Based on this figure, it can be concluded that the variable business behavior of batik business entrepreneurs during covid-19 was due to 3 main fentrepreneurs, namely:

1. Production efficiency has two sides, these are:

- Reducing production costs

- Adjusting the amount of production with purchasing power

2. Innovative which has 3 sides, these are:

- Perform product differentiation (make custom masks made of batik)

- Promoting through social media

- Marketing products using the digitization method

3. Creativity has two sides, these are:

- Varied designs and increase the aesthetic value of the product

- Shifting part of production to products that are used daily

Meanwhile, the following shows the results of Nvivo's output in the form of a project map of the business performance variables of batik business entrepreneurs during covid 19, as follows: 


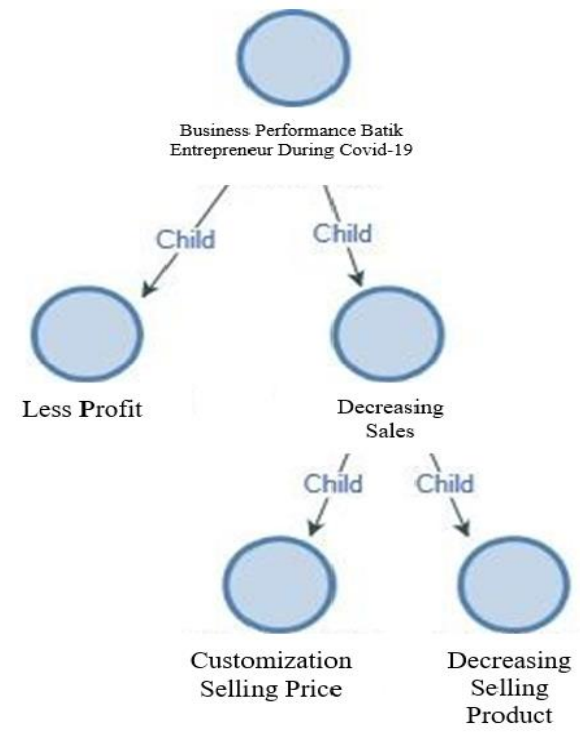

Figure 2. Business Performance Project Map of Batik Businesses During Covid-19

Figure 2 is an output result calculated by NVIVO software. Based on this figure it can be concluded that the business performance variable of batik business entrepreneurs during Covid-19 has 2 main fentrepreneurs, namely: reduced profits or decreased sales turnover. This declining sales turnover is further divided into 2 sides, namely, the selling price of the adjusted product and the decrease in the number of products sold.

Furthermore, the results of Nvivo's output in the form of a mind map can be seen in the following figure:

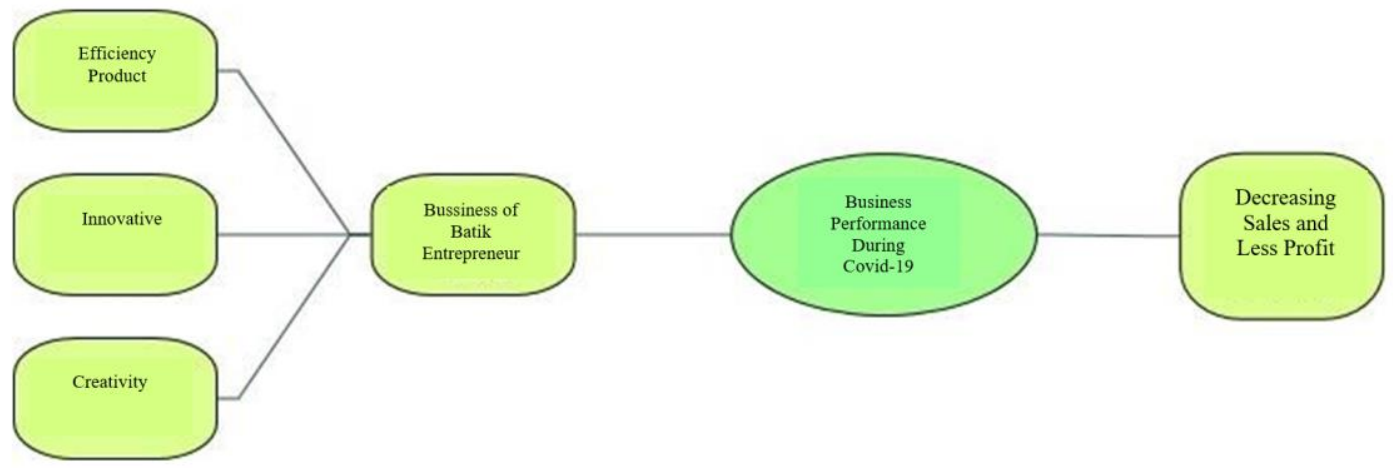

Figure 3. Mind Map

Figure 3 shows the pattern between the business behavior variables of batik businesses during Covid-19 and the business performance of batik businesses during Covid-19 with indicators that affect each of them.

Based on this explanation, it can be concluded that during Covid-19, batik business entrepreneurs in Jambi Province experienced a decline in their business activities. Observed through their business behavior, batik business entrepreneurs have 3 main things that must be considered, namely from the production efficiency factor, batik business entrepreneurs in Jambi Province must be able to:

- Reducing production costs

- Adjusting the amount of production with purchasing power

Then from the innovative fentrepreneurs in doing business, batik business entrepreneurs in Jambi Province must be able to:

- Perform product differentiation (for example by making custom masks made of batik)

- Promoting through social media, such as market places or social media such as Instagram, Facebook and so on

- Marketing products using the digitization method

Moreover, batik business entrepreneurs in Jambi Province must be creative and capable in:

- Create varied product designs and increase the aesthetic value of the product

- Shifting part of production to products that are used daily to make them more affordable for the community Meanwhile, in terms of performance, batik business entrepreneurs in Jambi Province also experienced a decline. This can be seen from 2 sides, namely reduced profits or profits and decreased sales turnover. In terms of declining sales turnover, it can be seen from business entrepreneurs who always adjust the selling 
price of their products so that they can be affordable by the public (lowering prices) and the decrease in the number of products sold during the pandemic.

The Covid-19 pandemic has made Batik business people in Jambi Province experience sluggishness. Based on the previous explanation, it can be concluded that the sluggishness of these business entrepreneurs can be seen from their business behavior and business performance. In terms of business behavior, it can be seen that the batik business in Jambi province is experiencing sluggishness due to 3 fentrepreneurs, namely Efficiency, Innovative and Creative, while in business performance fentrepreneurs, the sluggishness of batik business entrepreneurs in Jambi Province can be seen from 2 fentrepreneurs, namely reduced profits and profits. decreased sales turnover. This study supports research conducted (Sunarjo et al., 2021; Syaifullah et al., 2021) which states that purchasing systems during the pandemic tend to switch to electronic and cashless. This study also clarifies the research of (Christa \& Kristinae, 2021; Damilola et al., 2020; Fabeil et al., 2020) conducted regarding SMEs strategies during this pandemic.

Batik business people in Jambi Province must be able to be more creative and innovative in marketing their products. They can use a system that does not require much interaction with consumers, such as marketing their products online through e-commerce or creating their own social media that focuses on buying and selling batik in Jambi Province that is safe, easy and reaches many people. In addition, in order to make batik an important material today, batik business entrepreneurs must be able to make batik as another item that is ready to use and can be used daily, for example making masks that are currently being used by many people and adjusting the selling price so that accessible to many people.

\section{Conclusion}

The Covid-19 pandemic is experiencing sluggishness for Batik businesses in Jambi Province. This sluggish condition includes downturn in business behavior, namely efficiency, innovation and creativity. Downturn also occurs in business performance, namely the reduced profit or profit factor and decreased sales turnover.

\section{References}

Ameji, E. N., Taiga, U. U., \& Amade, M. A. (2020). Covid-19 Pandemic And Performance Of Small And Medium Scale Enterprises ( Smes ) In Lokoja , Kogi State , Nigeria. Ilorin Journal of Economic Policy, 7(3), 41-50.

Bartik, A., Bertrand, M., Cullen, Z., Glaeser, E. L., Luca, M., \& Stanton, C. (2020). How are Small Businesses Adjusting to COVID-19? Early Evidence from a Survey. SSRN Electronic Journal. https://doi.org/10.2139/ssrn.3574741

Christa, U. R., \& Kristinae, V. (2021). The effect of product innovation on business performance during covid 19 pandemic. Uncertain Supply Chain Management, 9(1), 151-158. https://doi.org/10.5267/j.uscm.2020.10.006

Damilola, O., Deborah, I., Oyedele, O., \& Kehinde, A.-A. (2020). Global pandemic and business performance: Impacts and responses. International Journal of Research in Business and Social Science, 9(6), 1-11. https://www.proquest.com/scholarly-journals/global-pandemic-business-performanceimpacts/docview/2478768375/se-2?accountid=17242

Evans, O. (2020). Socio-economic impacts of novel coronavirus: The policy solutions. Bizecons Quarterly, 7(March), 3-12.

Fabeil, N. F., Pazim, K. H., \& Langgat, J. (2020). The Impact of Covid-19 Pandemic Crisis on MicroEnterprises: Entrepreneurs' Perspective on Business Continuity and Recovery Strategy. Journal of Economics and Business, 3(2), 837-844. https://doi.org/10.31014/aior.1992.03.02.241

Gerald, E., Obianuju, A., \& Chukwunonso, N. (2020). Strategic agility and performance of small and medium enterprises in the phase of Covid-19 pandemic. International Journal of Financial, Accounting, and Management, 2(1), 41-50. https://doi.org/10.35912/ijfam.v2i1.163

Kumar, M. A., Syed, A. A., \& Pandey, A. (2020). How Adoption of Online Resources Can Help Indian SMEs in Improving Performance during COVID-19 Pandemic. Engineering \& Management, 83, 33943400. https://ssrn.com/abstract=3716696

Prabowo, A., Utami, Y. S., \& Simanjuntak, O. S. (2020). Revitalization Of Batik Tulis Giriloyo Small Business After The Covid-19 Pandemic Through The Storytelling Approach. 1(1), 127-132. https://doi.org/10.31098/pss.v1i1.188

Sayuti, R. H., \& Hidayati, S. A. (2021). The Influence of Pandemic Covid-19 on Small Business Enterprise in West Nusa Tenggara Province. Proceedings of the 2nd Annual Conference on Education and Social Science (ACCESS 2020), 556(Access 2020), 592-597. https://doi.org/10.2991/assehr.k.210525.156

Shafi, M., Liu, J., \& Ren, W. (2020). Impact of COVID-19 pandemic on micro, small, and medium-sized Enterprises operating in Pakistan. Research in Globalization, 2, 100018. https://doi.org/10.1016/j.resglo.2020.100018

Sharma, P., Leung, T. Y., Kingshott, R. P. J., Davcik, N. S., \& Cardinali, S. (2020). Managing uncertainty during a global pandemic: An international business perspective. Journal of Business Research, 116(May), 188-192. https://doi.org/10.1016/j.jbusres.2020.05.026 
Sunarjo, W. A., Nurhayati, S., \& Muhardono, A. (2021). Consumer Behavior Toward Adoption of Mobile Payment: A Case Study in Indonesia During the COVID-19 Pandemic. Journal of Asian Finance, Economics and Business, 8(4), 581-590. https://doi.org/10.13106/jafeb.2021.vol8.no4.0581

Syaifullah, J., Syaifudin, M., Sukendar, M. U., \& Junaedi, J. (2021). Social Media Marketing and Business Performance of MSMEs During the COVID-19 Pandemic. Journal of Asian Finance, Economics and Business, 8(2), 523-531. https://doi.org/10.13106/jafeb.2021.vol8.no2.0523

Zainuddin, M. T. (2020). Accelerating the Performance of Sme Business in Malaysia. E-Proceeding: Seminar Antarabangsa Islam Dan Sains (SAIS 2020), 1211-1232. 